\title{
UJI SELEKTIFITAS TRANSPOR Cu(II) TERHADAP Mg(II), Ca(II) DAN Sr(II) DENGAN ZAT PEMBAWA OKSIN DAN SDS SEBAGAI ADITIF MELALUI TEKNIK MEMBRAN CAIR FASA RUAH
}

\author{
Olly Norita Tetra, Zaharasmi K, Admin Alif, dan Frengky \\ Laboratorium Elektro/Fotokimia, Jurusan Kimia, FMIPA, Universitas Andalas Padang \\ Email : olly512@yahoo.com
}

\begin{abstract}
Selectivity of $\mathrm{Cu}$ (II) transport from the source phase containing $\mathrm{Mg}$ (II), $\mathrm{Ca}$ (II) and $\mathrm{Sr}$ (II) into the receiver phase had been researched by using oxine as carrier and Sodium Dodecyl Sulfate (SDS) as additive through bulk liquid membrane.The efficiency of the method depends on parameter (the $\mathrm{pH}$ of the donor and acceptor phase, effect of carrier concentrations, and time of transport). The selectivity of the method was assessed by performing the single, as well as the competitive transport experiment of $\mathrm{Mg}(\mathrm{II}), \mathrm{Ca}(\mathrm{II}$,$) and \mathrm{Sr}(\mathrm{II})$ ion and then $\mathrm{Cu}(\mathrm{II})$ percentage which was transported to receiver phase $99.98 \%$ and residue in source phase do not detect. The measurement was done to both of source phase and receiver phase by using Atomic Absorption Spectrophotometer (213.9 nm).
\end{abstract}

Keywords : Transport Cu(II), bulk liquid membrane, oxine, SDS, selectivity

\section{PENDAHULUAN}

Teknik membran cair fasa ruah adalah salah satu tipe dari membran cair yang telah banyak digunakan dalam pemisahan ion-ion logam. Dalam teknologi ini zat pembawa yang cocok merupakan hal yang sangat penting untuk pemisahan selektif suatu ion logam. Keberhasilan proses transpor ion logam melintasi membran ditentukan dari jumlah maksimum ion logam yang sampai ke fasa penerima, yaitu dengan mengatur teknis operasi difusi dan kestabilan kompleks antar fasa. Transpor ion logam yang akan dipisahkan melalui membran ke fasa penerima dapat dioptimalkan tanpa harus terjadi ekstraksi balik ${ }^{[1,2]}$.

Transpor $\mathrm{Cu}(\mathrm{II})$ melalui membran cair fasa ruah yang mengandung tetradentat Schiff base: $\quad$ N,N-bis(salicilidena)-naphtilen-1,8diamina (NBSND) sebagai zat pembawa sintetik yang sempurna telah diteliti ${ }^{[3]}$. Dalam sistem transpor ini, fasa penerima yang digunakan berupa larutan asam dengan penambahan sub milimolar surfaktan anionik seperti sodium dodecyil sulfate (SDS) yang dapat meningkatkan persentase tembaga yang tertranspor mencapai lebih $97 \%{ }^{[3]}$.

Optimalisasi proses transpor $\mathrm{Cu}(\mathrm{II})$ dengan memakai oksin sebagai zat pembawa telah pernah diteliti dan didapatkan jumlah $\mathrm{Cu}$ (II) yang tertranspor ke fasa penerima adalah 97,5\% dengan waktu transpor 6 jam $^{[4]}$. Penelitian kemudian dilanjutkan dengan penambahan SDS sebagai zat aditif dan ternyata mampu mempercepat waktu transpor menjadi 2 jam dengan persentase transpor $\mathrm{Cu}$ (II) ke fasa penerima sebesar $99,11 \%^{[5,6]}$. Sistem transpor yang diperoleh pada penelitian tersebut belum teruji keselektifannya terhadap kemungkinan keberadaan $\mathrm{Cu}$ (II) dalam bentuk campuran dengan ion-ion logam lain. Untuk itu perlu dilakukan uji keselektifan sistem transpor $\mathrm{Cu}$ (II) terhadap adanya $\mathrm{Mg}(\mathrm{II}), \mathrm{Ca}(\mathrm{II})$, dan $\mathrm{Sr}(\mathrm{II})$. Keselektifan sistem transpor dikontrol melalui pengaturan komposisi gabungan ionion tersebut di fasa sumber dan keberadaan masing-masing ion-ion logam setelah proses transpor di fasa sumber dan fasa penerima dimonitor dengan memakai Spektrofotometer Serapan Atom. 
Hasil penelitian ini diharapkan dapat melengkapi informasi dasar tentang selektifitas sistem transpor $\mathrm{Cu}$ (II) antar fasa terhadap ion-ion lain dalam bentuk campuran dengan memakai oksin sebagai zat pembawa dan SDS sebagai aditif sehingga penelitian ini dapat diaplikasikan untuk teknik pemisahan dan pemurnian $\mathrm{Cu}$ (II) baik dalam skala laboratorium maupun dalam skala industri.

\section{METODOLOGI PENELITIAN}

\section{Alat dan Bahan}

Alat-alat yang digunakan pada penelitian ini adalah : Spektrofotometer Serapan Atom model ALFA-4 London Inggris, pH-meter Stick Fisons, Sanwa digital tachnometer Model ISE-100, sel membran cair fasa ruah, stop watch, magnetik stirer, neraca analitik Ainsworth, dan alat-alat gelas lainnya.

Bahan yang digunakan antara lain: kloroform (Merck), oksin $\left(\mathrm{C}_{9} \mathrm{H}_{7} \mathrm{ON}: \quad\right.$ Merck), $\mathrm{CuCl}_{2} \cdot 2 \mathrm{H}_{2} \mathrm{O}, \mathrm{CaCl}_{2}, \mathrm{SrCl}_{2} \cdot 6 \mathrm{H}_{2} \mathrm{O}, \operatorname{logam} \mathrm{Mg}$ murni, asam sulfat $\left(\mathrm{H}_{2} \mathrm{SO}_{4}\right.$ : Merck), asam nitrat $\left(\mathrm{HNO}_{3}\right.$ : Merck), asam klorida $(\mathrm{HCl}$ : Merck), Sodium Dodecyl Sulfate $\left(\mathrm{NaC}_{12} \mathrm{H}_{25} \mathrm{SO}_{4}\right)$, larutan buffer (asam asetat dan natrium asetat), dan akuades.

\section{Prosedur Kerja}

\section{Pembuatan larutan fasa sumber}

Ditimbang sejumlah $1,3422 \mathrm{~g} \mathrm{CuCl} 2 \cdot 2 \mathrm{H}_{2} \mathrm{O}$, dilarutkan dalam $\mathrm{HCl} \quad 0,01 \quad \mathrm{M}$ sampai volumenya $1000 \mathrm{~mL}$. Larutan yang

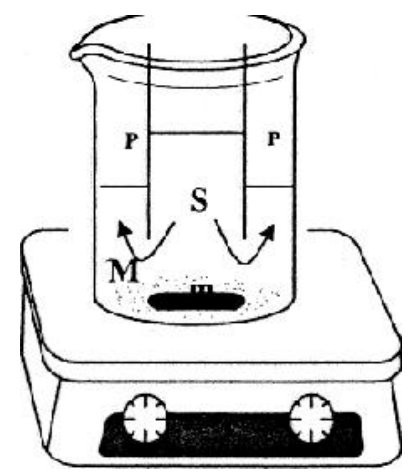

mengandung ion $\mathrm{Cu}(\mathrm{II})$ dengan konsentrasi $7,87 \times 10^{-3} \mathrm{M}$ (500 ppm), diambil sebanyak 2 $\mathrm{mL}$, dicampur berpasangan dengan ion $\mathrm{Mg}$, $\mathrm{Ca}$ dan $\mathrm{Sr}$ pada berbagai variasi konsentrasi dan diatur pHnya dengan memakai buffer asetat kemudian diencerkan dengan akuades ke dalam labu ukur $50 \mathrm{~mL}$ sampai tanda batas, sehingga diperoleh larutan $3,15 \times 10^{-4}$ M (20 ppm).

\section{Pembuatan larutan fasa membran}

Ditimbang sejumlah $0,1270 \mathrm{~g}$ oksin $(\mathrm{Mr}=$ $145,16 \mathrm{~g} / \mathrm{mol}$ ) dan dilarutkan dengan kloroform sampai volumenya $500 \mathrm{~mL}$. Larutan membran yang diperoleh adalah pelarut organik yang mengandung oksin 17,5 x $10^{-4} \mathrm{M}$ dalam kloroform.

\section{Pembuatan larutan fasa penerima}

Diambil sebanyak $8,34 \mathrm{~mL}$ asam sulfat dan dilarutkan dengan akuades sampai volumenya $1000 \mathrm{~mL}$. Larutan fasa penerima yang diperoleh adalah asam sulfat dengan konsentrasi 0,15 M. Kemudian SDS dipipet $25 \mu \mathrm{L}$ ditempatkan dalam fasa penerima, sehingga diperoleh konsentrasi SDS 1,458 x $10^{-4} \mathrm{M}$.

\section{Penentuan selektifitas membran kloroform yang mengandung zat pembawa oksin dan SDS sebagai aditif terhadap $\mathrm{Cu}$ (II) dalam adanya ion-ion logam lain melalui teknik membran cair fasa ruah}

Percobaan dilakukan dengan menggunakan reaktor seperti Gambar $1^{[3]}$.

Gambar 1. Model reaktor transpor $\mathrm{Cu}(\mathrm{II})$ melalui teknik membran cair fasa ruah. 

Larutan kloroform yang mengandung oksin $17,5 \times 10^{-4} \mathrm{M}$ sebanyak $20 \mathrm{~mL}$ ditempatkan pada dasar beker gelas yang mempertemukan 2 fasa larutan yaitu fasa sumber (di dalam tabung kaca silindris, diameter dalam 2,4 cm) dan fasa penerima (di bagian luar tabung kaca silindris, diameter dalam $4 \mathrm{~cm}$ ). Fasa sumber berisi $6 \mathrm{~mL} \mathrm{Cu}$ (II) 3,15 x $10^{-4} \mathrm{M}(20$ ppm) dengan $\mathrm{pH} 3$, sedangkan fasa penerima berisi $12 \mathrm{~mL}$ asam sulfat $0,15 \mathrm{M}$ yang mengandung SDS $1,458 \times 10^{-4} \mathrm{M}$. Pada bagian bawah lapisan organik ditempatkan magnetik stirrer dengan kecepatan $340 \mathrm{rpm}$. Larutan diaduk selama 2 jam, kemudian didiamkan untuk mencapai waktu kesetimbangan selama 15 menit. Banyaknya $\mathrm{Cu}$ (II) yang ditranspor ke fasa penerima dan yang bersisa di fasa sumber ditentukan dengan Spektrofotometer Serapan Atom.

Pada penelitian ini, ion $\mathrm{Cu}$ (II) pertama kali diuji dengan memasukkan $\mathrm{Cu}$ (II) secara berpasangan pada perbandingan mol tertentu dengan masing-masing ion $\mathrm{Mg}$ (II), $\mathrm{Ca}$ (II) dan $\operatorname{Sr}($ II). Kemudian dilanjutkan dengan mencampurkan keempat ion tersebut. Hal ini bertujuan untuk melihat sejauh mana selektifitas $\mathrm{Cu}$ (II) setelah ditranspor dari fasa sumber ke fasa penerima dengan oksin sebagai zat pembawa dan SDS sebagai surfaktan terhadap adanya ion $\mathrm{Mg}(\mathrm{II}), \mathrm{Ca}(\mathrm{II})$, dan $\operatorname{Sr}(\mathrm{II})$.

\section{HASIL DAN DISKUSI}

Pengaruh konsentrasi ion $\mathrm{Mg}(\mathrm{II}), \mathrm{Ca}(\mathrm{II})$, dan $\mathrm{Sr}$ (II) terhadap persentase $\mathrm{Cu}(\mathrm{II})$ dalam fasa sumber

Kestabilan kompleks yang terbentuk antara $\mathrm{Cu}(\mathrm{II})$ dengan oksin lebih stabil dibandingkan dengan ion $\mathrm{Mg}(\mathrm{II}), \mathrm{Ca}$ (II), dan $\mathrm{Sr}(\mathrm{II})$, mengakibatkan $\mathrm{Cu}(\mathrm{II})$ lebih mudah tertarik ke fasa membran untuk membentuk kompleks dengan oksin dari pada ion-ion yang lain $\left(\log \mathrm{K}_{\mathrm{Cu}-\mathrm{Oksin}}=12,2 ; \log \mathrm{K}_{\mathrm{Mg} \text {-Oksin }}=\right.$ 6,$38 ; \log \mathrm{K}_{\mathrm{Ca}-\mathrm{Oksin}}=7,3 ; \log \mathrm{K}_{\mathrm{Sr}-\mathrm{Oksin}}=$ $2,89)^{[7]}$.

Faktor pH larutan fasa sumber juga sebagai penentu tersisanya ion-ion tersebut dalam fasa sumber. Pada penelitian ini digunakan $\mathrm{pH} 3$ di fasa sumber, dan diketahui bahwa $\mathrm{pH}$ kompleks Cu-oksin 2,9 - 11 sedangkan kestabilan kompleks ion $\mathrm{Mg}(\mathrm{II}), \mathrm{Ca}(\mathrm{II})$ dan Sr(II) terjadi pada $\mathrm{pH} 9-13$, sehingga ionion tersebut tidak mampu menghalangi ion $\mathrm{Cu}(\mathrm{II})$ untuk berinteraksi dengan oksin ke dalam fasa membran ${ }^{[7]}$.

Tabel 1. Efisiensi transpor $\mathrm{Cu}$ (II) dengan adanya variasi konsentrasi ion lain pada fasa sumber

\begin{tabular}{cccc}
\hline & \multicolumn{3}{c}{$\% \mathrm{Cu}(\mathrm{II})$ sisa di fasa sumber } \\
\cline { 2 - 4 } & $\mathrm{Mg}(\mathrm{II})$ & $\mathrm{Ca}(\mathrm{II})$ & $\mathrm{Sr}(\mathrm{II})$ \\
\hline $\mathrm{Cons}):\left[\mathrm{M}^{+}\right]$ & $*$ & $*$ & $*$ \\
$1: 0$ & $*$ & $*$ & $*$ \\
$1: 1$ & $*$ & $*$ & $*$ \\
$1: 2$ & $*$ & $*$ & $*$ \\
$1: 4$ & $*$ & $*$ & $*$ \\
$1: 6$ & $*$ & $*$ & $*$ \\
$1: 8$ & $*$ & $*$ & \\
$1: 10$ & $: \mathrm{M}^{+}=$ion-ion logam lain $((\mathrm{Mg}(\mathrm{II}), \mathrm{Ca}(\mathrm{II}), \mathrm{Sr}(\mathrm{II}))$ & \\
& $*$ &
\end{tabular}

Kondisi Percobaan : Fasa sumber: $6 \mathrm{~mL} \mathrm{Cu}^{+2} 3,15 \times 10^{-4} \mathrm{M}$ dan ion logam lain dengan variasi konsentrasi pada $\mathrm{pH} 3$, Fasa membran: $20 \mathrm{~mL}$ kloroform yang mengandung oksin $17,5 \times 10^{-4} \mathrm{M}$, Fasa penerima: $12 \mathrm{~mL}$ asam sulfat $0,15 \mathrm{M}$ dan $1,458 \times 10^{-4} \mathrm{M}$ SDS, Waktu transpor: 2 jam, Waktu kesetimbangan: 15 menit. 
Pengaruh konsentrasi ion $\mathrm{Mg}(\mathrm{II}), \mathrm{Ca}(\mathrm{II})$, dan $\mathrm{Sr}$ (II) terhadap persentase $\mathrm{Cu}$ (II) dalam fasa penerima

Keberadaan $\mathrm{Mg}(\mathrm{II}), \mathrm{Ca}(\mathrm{II})$, dan $\mathrm{Sr}$ (II) pada perbandingan konsentrasi $1: 1$ dengan ion $\mathrm{Cu}$ (II) tidak mempengaruhi transpor ion $\mathrm{Cu}$ (II) sampai ke fasa penerima, ion $\mathrm{Cu}$ (II) yang tertranspor ke fasa penerima mencapai lebih dari 99\%. Kompetisi yang ketat di antarmuka fasa sumber dan fasa membran antara ion $\mathrm{Cu}$ (II) dengan pasangan ionnya terhadap oksin, merupakan gaya pendorong untuk terekstraksinya $\mathrm{Cu}(\mathrm{II})$ ke fasa membran. Kestabilan kompleks yang terbentuk antara $\mathrm{Cu}(\mathrm{II})$ dengan oksin lebih stabil dibandingkan dengan ion $\mathrm{Mg}(\mathrm{II})$, $\mathrm{Ca}$ (II) dan $\mathrm{Sr}(\mathrm{II})$, sehingga transpor ion $\mathrm{Cu}$ (II) masih efektif.

Gambar 2 memperlihatkan terjadinya sedikit penurunan transpor ion $\mathrm{Cu}$ (II) dengan adanya ion $\mathrm{Mg}$ (II) sebesar $4,81 \%$, adanya ion $\mathrm{Ca}$ (II) $3,88 \%$ dan ion $\operatorname{Sr}$ (II) $0,12 \%$, namun tidak mempengaruhi daya transpor $\mathrm{Cu}$ (II) ke fasa penerima. Hal ini dapat dijelaskan karena ukuran jari-jari ion $\mathrm{Mg}$ (II) yang lebih kecil daripada ion $\mathrm{Cu}(\mathrm{II}),\left(\mathrm{Cu}\right.$ (II) $=0,72 \mathrm{~A}^{\mathrm{o}}$; $\operatorname{Mg}($ II $)=0,65 \mathrm{~A}^{\mathrm{o}} ; \mathrm{Ca}(\mathrm{II})=0,99 \mathrm{~A}^{\mathrm{o}} ; \operatorname{Sr}(\mathrm{II})=$ $1,13 \mathrm{~A}^{0}$ ) mengakibatkan ion $\mathrm{Mg}$ (II) berkompetisi ketat dengan $\mathrm{Cu}(\mathrm{II})$ untuk mengikat oksin sehingga proses transpor ion $\mathrm{Cu}$ (II) sedikit terhalang pada antarmuka fasa membran dan fasa penerima.

\section{Persentase ion $\mathrm{Mg}$ (II), $\mathrm{Ca}$ (II) dan $\mathrm{Sr}$ (II) dalam larutan ion $\mathrm{Cu}$ (II) pada fasa sumber}

Faktor $\mathrm{pH}$ fasa sumber yang selektif untuk $\mathrm{Cu}$ (II) merupakan penyebab utama terjadinya selektifitas $\mathrm{Cu}$ (II) pada antarmuka fasa sumber dan fasa membran ${ }^{[9]}$. Persentase ion $\mathrm{Sr}$ (II) yang tersisa dalam fasa sumber relatif banyak dibandingkan dengan $\mathrm{Mg}$ (II) atau $\mathrm{Ca}$ (II). Hal ini terjadi karena ukuran jari-jari $\mathrm{Sr}$ (II) lebih besar daripada ion $\mathrm{Mg}$ (II) dan $\mathrm{Ca}$ (II) dan kestabilan kompleks yang terbentuk antara $\mathrm{Mg}$ (II) dengan oksin lebih stabil daripada ion $\mathrm{Sr}$ (II) dengan oksin sehingga ion $\operatorname{Mg}$ (II) lebih banyak masuk ke membran $^{[10]}$.
Semakin besar perbandingan konsentrasi ion $\mathrm{Mg}$ (II), $\mathrm{Ca}$ (II) dan $\mathrm{Sr}$ (II) dengan ion $\mathrm{Cu}$ (II) di dalam fasa sumber semakin besar pula persentase ion tersebut bersisa didalam fasa sumber diiringi dengan turunnya persentase transpor $\mathrm{Cu}(\mathrm{II})$ ke fasa penerima namun $\mathrm{Mg}(\mathrm{II}), \quad \mathrm{Ca}(\mathrm{II}), \quad$ dan $\mathrm{Sr}(\mathrm{II})$ tidak ikut tertranspor ke fasa penerima, karena kestabilan kompleks $\mathrm{Cu}$ (II) terhadap oksin jauh lebih besar dibandingkan dengan ion $\mathrm{Mg}(\mathrm{II}), \mathrm{Ca}(\mathrm{II})$, dan $\mathrm{Sr}(\mathrm{II})$. Adanya interaksi SDS di antar muka fasa membran dan fasa penerima menurunkan tegangan permukaan antar muka, dan menghambat lolosnya oksin ke fasa penerima ${ }^{[11]}$.

\section{Persentase Ion $\mathrm{Mg}$ (II), Ca(II) dan $\mathrm{Sr}$ (II) dalam larutan ion $\mathrm{Cu}$ (II) yangTertranspor ke fasa penerima}

Banyaknya $\mathrm{Mg}$ (II), $\mathrm{Ca}(\mathrm{II})$, dan $\mathrm{Sr}(\mathrm{II})$ yang terperangkap di fasa sumber (Gambar 3) berhubungan langsung dengan tidak tertranspornya ion-ion tersebut ke fasa penerima (Tabel 2). Adanya asam sulfat sebagai akseptor pada fasa penerima menyebabkan transpor $\mathrm{Mg}(\mathrm{II}), \mathrm{Ca}$ (II) dan $\mathrm{Sr}$ (II) tidak terekstraksi dengan baik karena protonasi $\mathrm{H}_{2} \mathrm{SO}_{4}$ lebih membantu dekompleksasi kompleks $\mathrm{Cu}$-oksin di antar muka fasa membran - fasa penerima daripada ion lain ${ }^{[12]}$.

Pengaruh campuran $\mathrm{Mg}(\mathrm{II}), \mathrm{Ca}(\mathrm{II})$ dan $\mathrm{Sr}$ (II) dalam larutan $\mathrm{Cu}$ (II) yang terdeteksi pada fasa sumber maupun fasa penerima

Hasil penelitian menunjukkan transpor $\mathrm{Cu}$ (II) yang sampai ke fasa penerima mencapai $99,92 \%$, sedangkan ketiga ion lainnya banyak bersisa di fasa sumber dan sedikit sekali yang terperangkap di fasa membran (Tabel 3). Hal ini karena peranan protonasi $\mathrm{H}_{2} \mathrm{SO}_{4}$ sebagai akseptor di fasa penerima yang membantu dekompleksasi kompleks $\mathrm{Cu}$-oksin di antar muka fasa penerima daripada ion lain. Selain itu dengan adanya SDS menurunkan tegangan permukaan antar muka fasa penerima dan menghambat lolosnya oksin ke fasa penerima. 


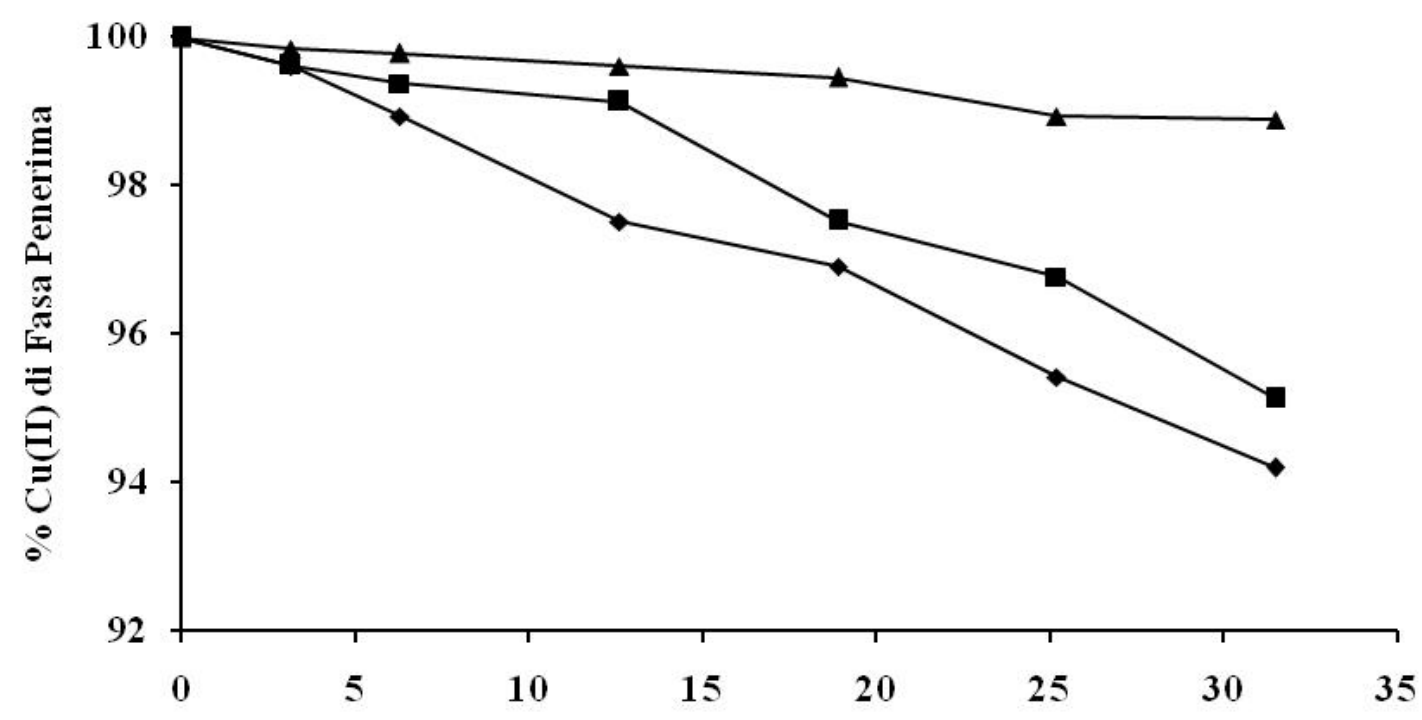

Konsentrasi ion logam (10-4)M

Gambar 2. Pengaruh konsentrasi ion $\operatorname{Mg}$ (II) ( - -), Ca(II) ( - -) dan $\operatorname{Sr}($ II) (- - ) terhadap persentase transpor ion $\mathrm{Cu}$ (II) dalam fasa penerima.

Kondisi Percobaan : Fasa sumber $6 \mathrm{~mL} \mathrm{Cu}^{+2} 3,15 \times 10^{-4} \mathrm{M}$ dan ion logam lain dengan variasi konsentrasi dengan $\mathrm{pH} 3$; Fasa membran, $20 \mathrm{~mL}$ kloroform yang mengandung oksin $17,5 \times 10^{-4} \mathrm{M}$ ; Fasa penerima, $12 \mathrm{~mL}$ asam sulfat $0,15 \mathrm{M}$ dan $1,458 \times 10^{-4} \mathrm{M}$ SDS ; Waktu transpor, 2 jam; Waktu kesetimbangan 15 menit.

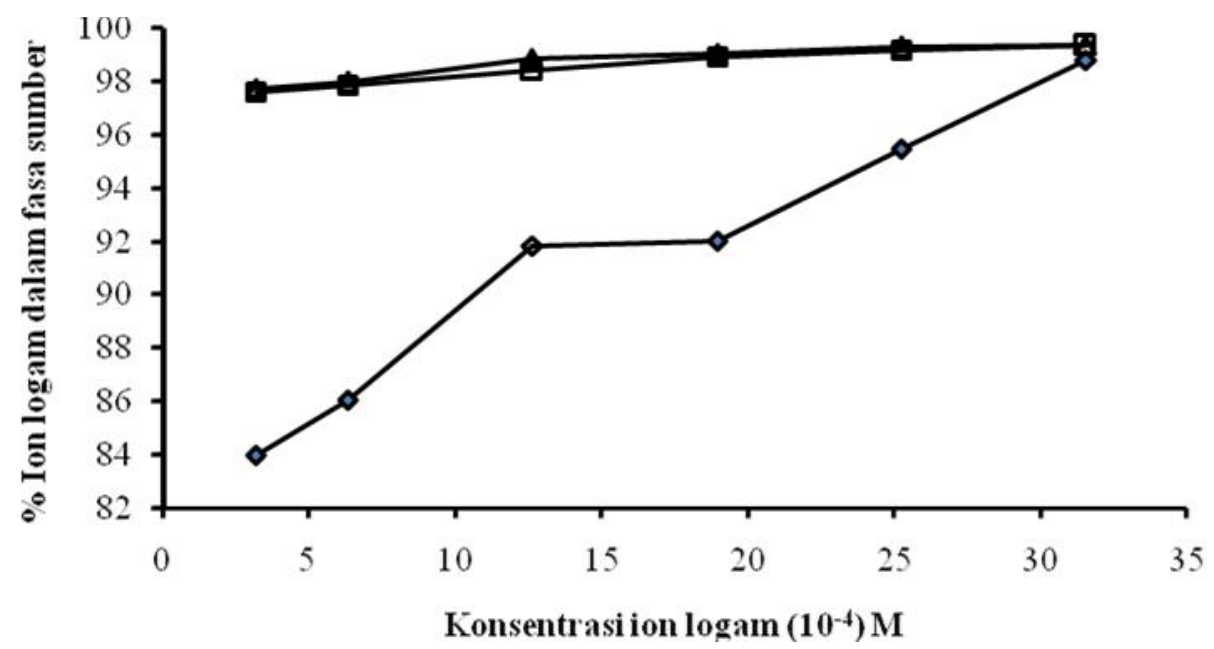

Gambar 3.Persentase ion $\mathrm{Mg}(\mathrm{II})$ ( - - -), Ca(II) ( - - ) dan $\mathrm{Sr}(\mathrm{II})$ (- - )sisa pada fasa sumber.

Kondisi Percobaan : Fasa sumber $6 \mathrm{~mL} \mathrm{Cu}^{+2} 3,15 \times 10^{-4} \mathrm{M}$ dan ion logam lain dengan variasi konsentrasi pada $\mathrm{pH} 3$; Fasa membran, $20 \mathrm{~mL}$ kloroform yang mengandung oksin $17,5 \times 10^{-4} \mathrm{M}$; Fasa penerima, $12 \mathrm{~mL}$ asam sulfat $0,15 \mathrm{M}$ dan $1,458 \times 10^{-4} \mathrm{M}$ SDS; Waktu transpor, 2 jam ; Waktu kesetimbangan 15 menit.

Selektifitas teknik membran cair fasa ruah terhadap transpor $\mathrm{Cu}(\mathrm{II})$ dalam adanya ion $\mathrm{Mg}(\mathrm{II}), \mathrm{Ca}(\mathrm{II})$ dan $\mathrm{Sr}(\mathrm{II})$

Uji selektifitas sistem transpor $\mathrm{Cu}(\mathrm{II})$ dihitung dengan menggunakan uji S. Hasil perhitungan menunjukkan bahwa teknik membran cair fasa ruah sangat selektif terhadap transpor $\mathrm{Cu}(\mathrm{II})$ pada fasa penerima yang mencapai $100 \%$ (Tabel 4). Hal ini membuktikan bahwa terjadi pemisahan yang sempurna terhadap transpor $\mathrm{Cu}(\mathrm{II})$. 
Tabel 2. Persentase $\mathrm{Mg}(\mathrm{II}), \mathrm{Ca}(\mathrm{II})$ dan $\mathrm{Sr}$ (II) dalam larutan $\mathrm{Cu}(\mathrm{II})$ yang tertanspor ke fasa penerima

\begin{tabular}{cccc}
\hline Perbandingan & \multicolumn{3}{c}{ Fasa Penerima } \\
Konsentrasi \\
{$[\mathrm{Cu}]:\left[\mathrm{M}^{+}\right]$} & $\% \mathrm{Mg}(\mathrm{II})$ & $\% \mathrm{Ca}(\mathrm{II})$ & $\% \mathrm{Sr}(\mathrm{II})$ \\
\hline $1: 1$ & $*$ & $*$ & $*$ \\
$1: 2$ & $*$ & $*$ & $*$ \\
$1: 4$ & $*$ & $*$ & $*$ \\
$1: 6$ & $*$ & $*$ & $*$ \\
$1: 8$ & $*$ & $*$ & $*$ \\
$1: 10$ & $*$ & $*$ & $*$ \\
\hline
\end{tabular}

Keterangan $\quad: \mathrm{M}+=$ ion-ion logam lain ((Mg(II), $\mathrm{Ca}(\mathrm{II}), \mathrm{Sr}(\mathrm{II}))$

$*$ = tidak terdeteksi

Kondisi Percobaan : Fasa sumber: $6 \mathrm{~mL} \mathrm{Cu}^{+2} 3,15 \times 10^{-4} \mathrm{M}$ dan ion logam lain dengan variasi konsentrasi dengan $\mathrm{pH}$ 3, Fasa membran: $20 \mathrm{~mL}$ kloroform yang mengandung oksin $17,5 \times 10^{-4} \mathrm{M}$, Fasa penerima: $12 \mathrm{~mL}$ asam sulfat $0,15 \mathrm{M}$ dan 1,458 x $10^{-4} \mathrm{M}$ SDS, Waktu transpor: 2 jam, Waktu kesetimbangan 15 menit.

Tabel 3. Persentase jumlah kation dalam campuran $\mathrm{Mg}$ (II), $\mathrm{Ca}$ (II), dan $\mathrm{Sr}(\mathrm{II})$ dengan $\mathrm{Cu}(\mathrm{II})$

\begin{tabular}{ccc}
\hline Kation & \% ion logam sisa di fasa sumber & \% ion logam di fasa penerima \\
\hline $\mathrm{Cu}^{+2}$ & $*$ & 99,92 \\
$\mathrm{Mg}^{+2}$ & 95,20 & $*$ \\
$\mathrm{Ca}^{+2}$ & 97,65 & $*$ \\
$\mathrm{Sr}^{+2}$ & 98,86 & $*$ \\
\hline
\end{tabular}

Keterangan $\quad: *$ tidak terdeteksi

Kondisi Percobaan : Fasa sumber: $6 \mathrm{~mL} \mathrm{Cu}^{+2} 3,15 \times 10^{-4} \mathrm{M}$ dan ion logam lain dengan variasi konsentrasi dengan $\mathrm{pH} 3$, Fasa membran: $20 \mathrm{~mL}$ kloroform yang mengandung oksin 17,5 x $10^{-4} \mathrm{M}$, Fasa penerima: $12 \mathrm{~mL}$ asam sulfat $0,15 \mathrm{M}$ dan 1,458 x $10^{-4} \mathrm{M}$ SDS, Waktu transpor: 2 jam, Waktu kesetimbangan 15 menit.

Tabel 4. Uji selektifitas transpor $\mathrm{Cu}(\mathrm{II})$ terhadap keberadaan $\mathrm{Mg}(\mathrm{II}), \mathrm{Ca}(\mathrm{II})$, dan $\mathrm{Sr}(\mathrm{II})$

\begin{tabular}{cccc}
\hline $\begin{array}{c}\text { Perbandingan } \\
\text { Konsentrasi } \\
{[\mathrm{Cu}]:\left[\mathrm{M}^{+}\right]}\end{array}$ & \multicolumn{3}{c}{ \% Selektifitas Ion $\mathrm{Cu}(\mathrm{II})$ ke Fasa Penerima } \\
\cline { 2 - 4 } $1: 1$ & $\mathrm{Mg}(\mathrm{II})$ & $\mathrm{Ca}(\mathrm{II})$ & $\mathrm{Sr}(\mathrm{II})$ \\
$1: 2$ & 100 & 100 & 100 \\
$1: 4$ & 100 & 100 & 100 \\
$1: 6$ & 100 & 100 & 100 \\
$1: 8$ & 100 & 100 & 100 \\
$1: 10$ & 100 & 100 & 100 \\
& 100 & 100 & 100 \\
\hline
\end{tabular}

\section{KESIMPULAN}

Dari hasil penelitian dapat disimpulkan bahwa transpor $\mathrm{Cu}(\mathrm{II})$ dengan adanya ion $\mathrm{Mg}(\mathrm{II}), \mathrm{Ca}(\mathrm{II})$, dan $\mathrm{Sr}(\mathrm{II})$ melalui teknik membran cair fasa ruah dengan zat pembawa oksin dan SDS sebagai zat aditif sangat selektif, baik secara berpasangan maupun dalam bentuk campuran ketiga ion. Persentase $\mathrm{Cu}(\mathrm{II})$ yang tertranspor ke fasa penerima mencapai $99,98 \%$ dan yang bersisa di fasa sumber tidak terdeteksi. Dari uji 
selektifitas, didapat tingkat keselektifan transpor $\mathrm{Cu}$ (II) ke fasa penerima mencapai $100 \%$, dimana ion $\mathrm{Mg}$ (II), $\mathrm{Ca}$ (II) dan $\mathrm{Sr}$ (II) terperangkap di fasa sumber dan fasa membran.

\section{DAFTAR PUSTAKA}

1. M. Mulder, Basic Principle of Membrane Technology, Kluwer Academic Publisher, Dordrencht, 244 259, 1991.

2. Z. Kahar, A. Alif, H. Aziz, dan Emriadi, Pengaruh ion $\mathrm{Fe}(\mathrm{III}), \mathrm{Ni}(\mathrm{II})$, $\mathrm{Cu}$ (II) dan $\mathrm{Cd}(\mathrm{II})$ terhadap transport $\mathrm{Co}$ (II) antar fasa (air-kloroform-air) melalui teknik membran cair fasa ruah. J. Kimia Andalas., 8(1), 29-33, (2002).

3. R. Ahmad, et al., Effect Of anionic surfactant of transport of copper(ii) throught liquid membrane containing a new synthesis schiff base. $J$ Separation And Purification Technology., 28-33, (2007).

4. O. N. Tetra, A. Alif, H. Aziz, dan Emriadi, Transpor ion tembaga (II) melalui membran cair fasa ruah, Jurnal Riset Kimia., 1(1), (2007).

5. O. N. Tetra, Z. Kahar, dan Refinel, Penambahan asam oleat terhadap sistem transpor $\mathrm{Cu}(\mathrm{II})$ dengan zat pembawa oksin melalui teknik membran cair fasa ruah, Jurnal Riset Kimia., 2(1), (2008).

6. Refinel dan O. N. Tetra, Kinetika transport $\mathrm{Cu}$ (II) oleh zat pembawa oksin dengan dan tanpa asam oleat melalui teknik membran cair fasa ruah, Jurnal Riset Kimia., 2(2), (2009).

7. Ringbom, Complexation in analytical chemistry, Interscience Publisher. New York, 1963, 315 - 400.

8. Nezhadali, M. Hakimi, and $M$. Heydari, Competitive bulk liquid membrane and extraction of $\mathrm{Cu}(\mathrm{II})$, $\mathrm{Ni}(\mathrm{II}), \mathrm{Zn}$ (II), and $\mathrm{Mn}$ (II) cations using 5-methyle-4[thiophen-2-yl-methylenamino]-3-thio-oxo-1,2,4-triazol-5-one and phtalic dicarboxaldehyde. EJournal of Chemistry., 5, 52-57, (2008).

9. Refinel, Z. Kahar, dan Y. Sahirra, Pengaruh konsentrasi ion $\mathrm{Ca}(\mathrm{II})$, $\mathrm{Mg}$ (II) dan $\mathrm{Sr}(\mathrm{II})$ terhadap optimasi transpor Cd(II) dengan zat pembawa oksin melalui membran cair fasa ruah, Jurnal Kimia Andalas., 11(2), 16-22, (2005).

10. Z. Kahar, Mempelajari peranan oksin sebagai zat pembawa Co(II) antar fasa (air-kloroform-air) melalui teknik membrane cair fasa ruah, J. Kimia Andalas., 8(2), 29-33, (2002).

11. R. J. Milton, Surfactan and interfacial phenomena, A. Willey Interscience Publication. John Willey and Sons, New York, 1978, 55-58.

12. A. Alif, O. N. Tetra, H. Aziz, dan Emriadi, Pengaruh ion $\mathrm{Cd}(\mathrm{II})$ dan $\mathrm{Fe}$ (II) terhadap transport $\mathrm{Cu}$ (II) melalui teknik membran cair fasa ruah, Jurnal Kimia Andalas., 11(2), (2005). 